NBER WORKING PAPER SERIES

\title{
DID BLUE CROSS AND BLUE SHIELD SUFFER FROM ADVERSE SELECTION? EVIDENCE FROM THE 1950s
}

\author{
Melissa A. Thomasson \\ Working Paper 9167 \\ http://www.nber.org/papers/w9167 \\ NATIONAL BUREAU OF ECONOMIC RESEARCH \\ 1050 Massachusetts Avenue \\ Cambridge, MA 02138 \\ September 2002
}

This research would not have been possible without the generous assistance of NSF Grant \#SBR-9632121. I would like to thank Pat Bova and the National Opinion Research Center for allowing me access to the data. Bill Collins, Bill Even, Price Fishback, Carl Schertmann, Chuck Thomas and Bill Hutchinson made many helpful suggestions, as did seminar participants at the Southern Economic Association meetings, Indiana University, the World Cliometrics Congress, the Federal Trade Commission and Rutgers University. All errors remain my responsibility. The views expressed herein are those of the authors and not necessarily those of the National Bureau of Economic Research.

(C) 2002 by Melissa A. Thomasson. All rights reserved. Short sections of text, not to exceed two paragraphs, may be quoted without explicit permission provided that full credit, including $(\mathbb{C}$ notice, is given to the source. 
Did Blue Cross and Blue Shield Suffer from Adverse Selection? Evidence from the 1950s Melissa A. Thomasson

NBER Working Paper No. 9167

September 2002

JEL No. I11, N72

\section{$\underline{\text { ABSTRACT }}$}

This paper uses a unique data set from 1957 to examine whether or not Blue Cross and Blue Shield suffered from an adverse selection death spiral after for-profit commercial insurance companies entered the market for health insurance. Results suggest that moving to experience rating may have helped the Blues counteract adverse selection in the group health insurance market. Adverse selection posed a greater problem for the Blues in the market for individual health insurance, possibly because of differences in the way the Blues screened potential enrollees relative to commercial insurance companies.

Melissa A. Thomasson

Department of Economics

Miami University

Oxford, OH 45056

and NBER

thomasma@muohio.edu 


\section{INTRODUCTION}

Mandated community rating - the practice of restricting the ability of insurance companies to rate potential policyholders based on age, gender, or other risk factors - has been proposed or implemented in several states since the 1990s as a means of increasing insurance coverage among high-risk groups who would otherwise not be able to afford coverage. In the absence of community rating, insurance companies use experience rating, charging each subscriber a rate based on his or her expected claims. Thus, younger, healthier enrollees pay lower premiums than older enrollees. While the goal of community rating reforms is to increase coverage in the market, there is some concern that requiring insurance companies to charge everyone in a market the same rate may lead to an "adverse selection death spiral" in which younger, healthier enrollees actually abandon coverage as their premiums rise (Cutler and Zeckhauser, 1997; Cutler and Reber, 1998).

The evidence on whether or not adverse selection death spirals resulted when mandated community rating reforms were implemented in the 1990s is mixed. Some papers argue that adverse selection death spirals generated a reduction in insurance coverage in affected markets, while others find that insurance reforms caused virtually no change in insurance coverage (see Buchmueller and DiNardo, 2002). This paper sheds light on this issue by looking at the health insurance market from an historical perspective. Originally, Blue Cross and Blue Shield (the Blues) community rated all of their policies, since one of their purported goals was to extend access to medical services to all segments of the population (Eilers, p. 210). However, over time most Blue Cross and Blue Shield plans abandoned community rating. ${ }^{1}$ Was this because the Blues experienced a situation similar to that of an adverse

\footnotetext{
${ }^{1}$ Because they community rated their policies, the Blues were allowed to incorporate as nonprofit organizations in the 1930s and receive tax-exempt status (see Eilers, 1963 and Reed, 1947 for greater discussion of the birth of the Blues). However, the federal tax exemption that the Blues enjoyed was limited in 1986 after a GAO report concluded that there was very little difference in the rating practices of the nonprofit Blues and the for-profit commercial insurance companies (GAO, 1986, p. 2). Subsequently, after a 1994 change repealed the requirement in the Blue Cross and Blue Shield licensing law that plans be nonprofit, several Blue Cross and Blue Shield plans elected to drop their nonprofit status (and the rating restrictions that accompanied it) and convert to for-profit corporations. See Cunningham, pp. 215, 247-48 and Sherrid, pp. 51-52.
} 
selection death spiral as their enrollees abandoned the Blues in favor of less expensive coverage from commercial health insurance firms?

Using a unique data set from 1957, this paper compares the characteristics and medical expenditures of Blue Cross and Blue Shield enrollees with those of commercial firms in order to examine how selection may have affected the Blues. The data used are ideal for looking at this issue because they provide a snapshot of the health insurance market at a time when Blue Cross and Blue Shield community rated the majority of their policies while competing with for-profit, commercial health insurance companies that engaged in experience rating. Despite the fact that the Blues mostly engaged in community rating, results show that in the group market, the Blues did not attract poor risks relative to their commercial counterparts. However, in the individual market, analysis confirms that the Blues did suffer from adverse selection that may have ultimately led them to abandon community rating.

\section{THE 1950s HEALTH INSURANCE MARKET}

In the 1950s, the nonprofit Blue Cross and Blue Shield plans and the for-profit commercial insurance companies provided health insurance on either a group or an individual basis, with group contracts accounting for 68 percent of commercial insurance company business (Source Book of Health Insurance Data, 1976-1977, p. 23). ${ }^{2}$ Health insurance plans in the 1950 s were simpler than they are today. Blue Cross provided room and board hospital service benefits, in which the Blue Cross plan reimbursed hospitals directly (and in full) for providing room and board to subscribers. Blue Shield covered surgical fees and physicians' charges during a patient's hospital stay. Rarely, Blue Shield plans covered visits to doctors' offices. Some Blue Shield plans also operated on a service benefit basis, reimbursing physicians directly for charges in full. However, Blue Shield plans usually only offered service benefits to patients under a certain income level. More frequently, Blue Shield plans reimbursed

\footnotetext{
${ }^{2}$ While Blue Cross and Blue Shield do not separately report the number of group and individual subscribers, Eilers estimates that roughly three-quarters of Blue Cross and Blue Shield business came from group contracts (Eilers 1963, p. 27).
} 
physicians according to a fee schedule, and then physicians could balance bill patients for the difference between their customary charge and the Blue Shield reimbursement (Eilers, 1963; Reed, 1947). ${ }^{3}$

Both Blue Cross and Blue Shield plans community rated their policies. Thus, the plans charged low risks and high risks alike the same, average rate. ${ }^{4}$ When the plans first formed in the 1930 s, the Blues faced little competition since commercial, for-profit insurance companies were reluctant to insure a commodity that they believed would suffer from severe adverse selection and moral hazard (Eilers, 1963, p. 13). However, the Blues showed that problems with adverse selection could be overcome by insuring groups of relatively healthy workers, and that moral hazard could be limited by predominantly writing insurance contracts that replaced traditional indemnity benefits with service benefits for hospital care and physicians' service during a patient's hospitalization. After witnessing the success of Blue Cross and Blue Shield, commercial firms entered the health insurance market in the 1940s and the market grew rapidly. While only 9 percent of the population had health insurance coverage in 1940, 68 percent of the population carried health insurance by 1960 (Source Book of Health Insurance Data, 1976-1977, p. 22).

In contrast to the service benefits offered by the Blues, policyholders insured by commercial companies were usually billed by the hospital, and received an indemnity benefit from the insurance company that may or may not have covered the full bill. Indemnity benefits were also offered for surgery (according to a set fee schedule), and for physicians' charges during a patient's hospitalization. Benefits were typically stated in terms of dollars paid per day. For example, for a child having surgery to have her tonsils out, the plan may have paid $\$ 10$ per day in room and board to cover hospital charges, and up to $\$ 75$ in surgical fees.

\footnotetext{
${ }^{3}$ Out of 61 Blue Shield plans surveyed in 1954, only one offered only service benefits. Thirty-seven offered combination service and indemnity benefits, and 23 offered only indemnity benefits regardless of income. ("Health Inquiry: Voluntary Health Insurance." Hearings before the Committee on Interstate and Foreign Commerce, House of Representatives, $83^{\text {rd }}$ Congress, second session, on “Available Health Plans and Group Insurance," Part 7, 1954, pp. $2564 \mathrm{~b}-2564 \mathrm{~d}$.

${ }^{4}$ Technically, Blue Cross and Blue Shield determined a community's rate by combining the experience of covered groups, and no modifications were made on a particular group's rate if its experience differed from the average of the entire class. Blue Cross and Blue Shield plans did rate group and individual members differently, and charged different rates for single members, members with one dependent, and members with families. See Eilers, pp. 89-90 for greater discussion.
} 
Commercial insurance companies used experience rating to price their policies. Under a system of experience rating, the morbidity experience of the policyholders is taken into account when the premium is determined. Thus, healthy subscribers who use little care will pay a lower premium for a given quantity of insurance than a subscriber who is less healthy. Experience rating allowed the commercial plans to charge lower rates than Blue Cross and Blue Shield for the lowest risk subscribers, leaving the Blues with the high-cost policyholders. By 1950, commercial insurance companies accounted for 45 percent of health insurance market share, as shown in Figure 1 (Source Book of Health Insurance Data 1976-1977, p. 23).

\section{HOW DID SELECTION AFFECT THE BLUES?}

In describing the situation faced by the Blues after commercial firms entered the market, Eilers states:

Blue Cross and Blue Shield thus had some of their largest groups switch to coverages offered by insurance companies. A perplexing enigma developed. The departure of low-loss groups would leave Blue Cross-Blue Shield with predominantly high-loss elements. Rates would have to be increased. Higher rates in themselves would discourage the continuation of favorable groups remaining with the Blues, as well as deter those considering membership...(p. 215).

In other words, anecdotal evidence indicates that the Blues may have been facing an adverse selection death spiral as their healthiest subscribers left Blue Cross and Blue Shield for newly available, less expensive commercial health insurance policies. In response, the Blues began to experience rate at least some of their group policies in the 1950s, while maintaining community rating in the individual market. Table 1 shows the extent to which Blue Cross and Blue Shield plans engaged in experience rating in 1959. ${ }^{5}$ As shown in Table 1, less than one-third of Blue Cross/Blue Shield plans nationwide relied solely on community rating by 1959 , while most plans combined community rating with experience rating for some group subscribers (Eilers, p. 218).

\footnotetext{
${ }^{5}$ Unfortunately, while the aggregate proportion of Blue Cross/Blue Shield plans that engaged in experience rating is known, it is not known specifically which plans engaged in experience rating.
} 
The implementation of experience rating by the Blues should have tempered the effect of the adverse selection death spiral. If experience rating did help the Blues in the group market, then medical expenditures for Blue Cross and Blue Shield group plan enrollees should not have been strikingly higher than expenditures for people enrolled in commercial group plans that provided similar benefits. Further, there should not be evidence of differential selection between Blue Cross and Blue Shield compared to commercial health insurance companies in the group health insurance market.

Although the Blues may not have experienced a greater degree of adverse selection than commercial health insurance firms in the group market, this may not have been the case in the individual health insurance market. In the individual market, the Blues may have been more severely impacted by adverse selection than commercial insurance companies. ${ }^{6}$ While commercial health insurance companies used rigorous criteria to screen potential individual contracts, the Blues used much less aggressive screening techniques. Some commercial insurance companies refused to even offer individual coverage, and those that did often required that prospective enrollees undergo a physical examination before they could buy insurance. ${ }^{7}$ In contrast, potential individual subscribers could obtain coverage through Blue Cross and Blue Shield by simply filling out a "health statement." ${ }^{\prime 8}$ Blue Cross/Blue Shield officials were obviously aware of the potential for adverse selection in these circumstances, stating that in the case of individual enrollment,

\footnotetext{
${ }^{6}$ Insurance companies were aware of the potential for severe adverse selection in the individual market. Reed (1947) describes a situation where some of the first Blue Cross plans offered individual coverage to all-comers, with "unhappy" results (pp. 61-62). In testimony before Congress in 1954, several witnesses discussed the problems that were associated with individual coverage. One witness, the Executive Vice President of the Health Information Foundation (a nonprofit organization founded to study the social and economic aspects of health and illness), stated that "... the whole problem of health insurance breaks down into those covered by groups and those covered through individual contracts...there have to be precautions taken in admitting individuals, and various restrictions, and so on" (House of Representative Hearings, p. 2084).

${ }^{7}$ Out of four health insurance plans not affiliated with a specific firm or union that were surveyed for a Congressional hearing regarding voluntary health insurance coverage, one plan did not enroll individuals at all. Of the three plans that enrolled individuals, one required a physical examination under all circumstances and had an age limit of 50, another required physical exams in some cases, and the third accepted individual enrollees subject to a medical questionnaire (House of Representative Hearings, pp. 2529-35).

${ }^{8}$ When Congress questioned a Blue Cross official about their individual contracts, the official replied, "We allow individual enrollment without any limitation except that in the case of individuals, we require a health statement....That is all. There is no medical statement" (House of Representative Hearings, pp. 2323).
} 
There is a degree of selection against the plan where there is individual enrollment which does not exist when you get a cross section of the group. In other words, a man frequently knows that he is going to have hospitalization and he applies for it, and he forgets to mention in his application that he is expecting to go to the hospital" [emphasis added] (House of Representative Hearings, p. 2324).

Thus, while commercial health insurance companies often required potential enrollees to complete a detailed application and undergo a physical examination prior to enrollment, Blue Cross and Blue Shield required only that they give a health statement. This practice enabled people with unobservable medical conditions to buy health insurance coverage from the Blues, even though they may not have been able to even purchase health insurance from commercial insurance companies. These people would spend more on average than otherwise similar enrollees, thus driving up costs and premiums and possibly leading to an adverse selection death spiral. ${ }^{9}$

\section{DATA}

If the Blues were indeed subject to a greater degree of adverse selection in the individual market than were commercial health insurance companies, then there should be evidence that the Blues attracted "sicker" people—in other words, that the Blues suffered from greater adverse selection based on unobservable characteristics. In order to test this hypothesis, this paper relies on data from the from the National Opinion Research Center's (NORC) Nationwide Family Expenditures Surveys of 1958 (Anderson, Collette and Feldman, 1963). As part of its plan to understand the types of medical expenses American families were incurring and discover how they were meeting those expenses, the NORC surveyed almost 3,000 U.S. families in 1958. The NORC surveys provide detailed information about each family's medical expenditures and health insurance coverage in 1957, as well as information about the family's socioeconomic and demographic characteristics. The surveys are useful in understanding the

\footnotetext{
${ }^{9}$ Blue Cross and Blue Shield also made it easier for people terminating their group health insurance contracts to convert to individual contracts. While commercial insurance companies limited this practice of "group conversion," Blue Cross and Blue Shield plans were required by statute to grant conversion rights as long as the employee had been covered at least three months prior to leaving the workplace (Eilers, p. 171). This may have increased adverse selection, given that group conversion was voluntary.
} 
nature of competition in the 1950s insurance market because they specifically asked insured households about whether they carried insurance through Blue Cross/Blue Shield or a different plan, and whether they obtained their insurance through a group or individually. Families were contacted in advance of the survey, and asked to collect information on annual medical expenditures and health insurance coverage. The NORC attempted to verify each family's hospital expenditures with the hospital that provided the service. Summary statistics for the data set are reported in Table 2.

There are several ways to compare enrollees of Blue Cross and Blue Shield plans with those of for-profit, commercial insurance companies. One way is to look at simple means. If Blue Cross and Blue Shield tended to insure more costly subscribers, either because they community rated their policies or because they screened applicants less rigorously than commercial firms, then their enrollees may have spent more on medical care than did enrollees in commercial plans. ${ }^{10}$ Blue Cross and Blue Shield subscribers may also have been more likely to have a chronic condition. Table 3 provides summary statistics for families with group and individual insurance by type (Blue Cross/Blue Shield or commercial), and for uninsured families.

Compared to uninsured families, families with any kind of insurance (either Blue Cross/Blue Shield or commercial, individual or group) were much more likely to be employed, and to have had a younger household head. Insured families were also less likely to have a family member with a chronic illness, and they tended to be more educated than uninsured families. Uninsured families lost an average of 45 days of work due to illness, compared to 23 days for families with commercial group insurance and 38 days for families with individual Blue Cross/Blue Shield policies. However, despite the fact that uninsured families missed more work due to illness and were more likely to have a chronically ill family member, the mean medical expenditures of uninsured families were much lower than for insured

\footnotetext{
${ }^{10}$ Note that insuring costly subscribers is not alone indicative of the existence of adverse selection-e.g., it might only indicate the presence of a separating equilibrium where sicker people choose community rated plans, pay higher premiums, and have greater medical expenditures than healthier people who choose experience rated plans, pay lower premiums, and have lower medical expenditures (see Rothschild and Stiglitz 1976). Comparing medical expenditures to gauge the presence of adverse selection is only useful to the extent that plan premiums and characteristics are also considered.
} 
households. Overall, mean total medical expenses for uninsured households equaled $\$ 314$, compared to a high of $\$ 559$ for families with an individual contract through a commercial insurance company. ${ }^{11}$

Among insured families, columns 2 and 4 in Table 3 suggest that families with group insurance through the Blues were very similar to families with commercial group insurance in terms of observable characteristics such as age of the household head, employment, income, and education. In addition, mean expenditures on hospital care were roughly similar (\$252 for the Blues v. \$216 for commercial plans), as were mean total medical expenditures (\$496 for families insured with the Blues v. \$459 for families insured with commercial firms), and mean insurance policy benefit levels. Blue Cross/Blue Shield group subscribers had a mean hospital benefit level of $\$ 11.34$ per day, compared to $\$ 11.62$ for commercial policyholders. Average surgical benefits were also similar: \$289 for Blue Cross/Blue Shield and \$273 for commercial firms. Mean premiums paid by enrollees are also similar, although group enrollees in Blue Cross and Blue Shield paid somewhat more per month than did group enrollees in commercial plans (\$7.03 v. \$6.27). Looking only at simple means, then, Blue Cross and Blue Shield plans were similar to commercial firms in the group health insurance market and did not appear to suffer unduly from adverse selection.

Overall, compared to enrollees in the group market, enrollees in the individual market (regardless of whether they were insured through the Blues or through a commercial plan) were older, had lower average incomes, and were less likely to be employed. They were also more likely to suffer from chronic illness. Comparing commercial firm enrollees with Blue Cross/Blue Shield subscribers in the individual health insurance market shows that their observed characteristics were much the same. The mean age of the household head was similar for both Blue Cross/Blue Shield and commercial firms, as was the number of families who report having a member with a chronic illness. About 70 percent of all insured families in the individual market had an employed household head. With respect to premiums, enrollees in Blue Cross and Blue Shield plans paid \$7.38 per month on average, compared to $\$ 7.62$ per month for

\footnotetext{
${ }^{11}$ For insured households, total medical expenditures include amounts paid by the household and amounts paid by insurance.
} 
commercial individual subscribers. The Blue Cross/Blue Shield plans were somewhat more generous with respect to benefits than the commercial plans. Families insured under an individual contract through Blue Cross and Blue Shield reported a mean per diem hospital benefit of $\$ 10$ and a mean surgical benefit of \$264, compared to $\$ 8.82$ and $\$ 214$ for families insured with commercial firms.

With respect to medical expenditures, families insured with the Blues reported mean annual hospital expenditures of $\$ 288$, versus $\$ 172$ for families insured through individual commercial plans. Mean total medical expenses were $\$ 558$ for the individual Blue Cross/Blue Shield families, compared to \$356 for families with commercial insurance. Thus, even though observable characteristics between the two groups were very similar and enrollees in Blue Cross and Blue Shield paid less on average, medical expenditures for the Blues were much higher.

This difference in medical expenditures even though observable characteristics were similar might be partially explained by moral hazard. For example, as noted above, Blue Cross and Blue Shield provided more generous benefits under individual contracts than did commercial firms, so that Blue Cross and Blue Shield enrollees may have subsequently spent more on medical care. However, the difference in average benefits does not appear sufficient to explain the large difference in medical expenditures between Blue Cross/Blue Shield families and families insured through commercial health insurance companies.

An alternative explanation may be that the differences in medical expenditures despite similar observable characteristics occurred because of selection based on unobservable characteristics. Unlike commercial health insurance companies, Blue Cross and Blue Shield did not rigorously screen potential applicants, and were required to accept group-conversion enrollees. Thus, persons with unobservable medical conditions that could be discovered in a physical exam would have tended to purchase insurance through the Blues rather than from a commercial health insurance company. ${ }^{12}$ In other words, the Blues may have suffered from adverse selection.

\footnotetext{
${ }^{12}$ Group-conversion subscribers had higher expenses than any other Blue Cross/Blue Shield category. The mean medical expenditures associated with group conversion subscribers were $\$ 655$, compared to $\$ 497$ for regular
} 


\section{ECONOMETRIC FRAMEWORK}

In order to separate the effects of moral hazard from adverse selection, it is necessary to use a more rigorous approach to compare Blue Cross/Blue Shield enrollees with commercial health insurance company subscribers. To more thoroughly examine the differences in medical expenditures and characteristics of Blue Cross/Blue Shield enrollees compared to commercial health insurance subscribers, two separate techniques are used. First, OLS is used to determine if differences in medical expenditures between Blue Cross/Blue Shield and commercial health plan enrollees persist even after controlling for differences in other variables. Because the OLS model does not control for unobservable selection into Blue Cross/Blue Shield and commercial health plans, a technique to account for such selection is then used to more adequately compare these plans and gain insights into whether or not the Blues suffered from greater adverse selection than did commercial plans.

Table 4 reports the results of OLS regression analysis on the natural logarithm of annual medical expenditures, controlling for insurance type. The differences in medical expenditures between Blue Cross/Blue Shield and commercial health plan enrollees persist even after controlling for differences in age, income, and other variables. As Table 4 shows, individual Blue Cross and Blue Shield policyholders spent much more than any other insured category, spending 56 percent more than the uninsured population. In contrast, individual commercial subscribers spent only 26 percent more on medical care than the uninsured, while both Blue Cross/Blue Shield and commercial group subscribers spend about 40 percent more.

The similarity of the estimated coefficients on the Blue Cross/Blue Shield-group and commercialgroup insurance dummies reported in Table 4 supports the notion that Blue Cross and Blue Shield group plans were no more likely to attract worse risks than commercial group plans. In contrast, the differences between the estimated coefficients on the Blue Cross/Blue Shield-individual and commercial-individual insurance dummies reinforce the hypothesis that in the individual market, the Blues may have suffered

individual (not group conversion) Blue Cross/Blue Shield subscribers and \$494 for Blue Cross/Blue Shield group subscribers. 
from adverse selection relative to commercial plans. In fact, commercial plans in the individual market had the lowest expenditures of any insured category — a fact that is not surprising given that families who wanted to purchase individual insurance from commercial insurance company faced rigorous screening.

One problem with the estimates presented in Table 4 is that they capture the effects of both moral hazard and adverse selection. That is, the estimated coefficients on the type of insurance dummies captures both the effect of having insurance on medical spending (moral hazard) and the fact that families with unobservable characteristics leading them to spend greater amounts on medical care may have been the ones who chose to purchase insurance (adverse selection). Even though the mean benefit levels of the various types of plans reported in Table 3 are very similar, suggesting that the most of the difference in the estimated coefficients is probably not due to moral hazard, a more rigorous approach that separates the effect of adverse selection from moral hazard is warranted.

In order to separate the effects of moral hazard from adverse selection and to provide a more rigorous test of whether or not differential selection between the Blues and commercial insurance companies occurred in the 1950 s, it is necessary to use a polychotomous selection model that is designed to explicitly control for differential selection into either Blue Cross/Blue Shield or commercial health insurance plans. The group and individual markets are examined separately using a technique that is a generalization of the polychotomous selection model offered by Heckman (1976, 1979), Hay (1980), Dubin and McFadden (1984), and Schmertmann (1994). In this case, a household is either in the group health insurance market or the individual market. In each market, a household has three choices with respect to insurance: to be uninsured, to insure with Blue Cross, or to insure with a commercial insurance company. Thus, the household's insurance decision can be expressed as:

[1] $\quad I_{m}^{*}=z_{m}{ }^{\prime} \gamma_{m}+v_{m}(\mathrm{~m}=1,2,3)$,

where $v_{m}$ are iid normal random variables with zero mean and variance $\sigma_{v m}^{2} \cdot I_{m}^{*}$ is a polychotomous variable such that the $\mathrm{m}^{\text {th }}$ category is chosen $(\mathrm{I}=\mathrm{m})$ iff 
[2] $\quad\left(z_{m}^{\prime} \gamma_{m}-z_{j}^{\prime} \gamma_{j}\right)>\left(v_{j}-\mathrm{v}_{\mathrm{m}}\right) \forall m \neq j$.

For ease of notation, let $\left(z_{m}{ }^{\prime} \gamma_{m}-z_{j}^{\prime} \gamma_{j}\right)=\tau_{m j}$ and $\left(v_{j}-v_{m}\right)=\omega_{m j}$. Then $I_{m}=m \Leftrightarrow \tau_{m j}>\omega_{m j}, \forall m \neq j$.

In this form, the polychotomous model with three choices is reduced to a model with $M-1=2$ binary

decision rules that can be estimated separately for the individual and group markets using bivariate probit

(see Maddala, 1983). The estimates from the first-stage bivariate probit (reported in Appendices 1A and

1B) can then be used to construct two linear, conditional expectation selection correction terms that are

used in the second-stage OLS estimation of the natural log of total medical expenditures for both group

(equation 3) and individual (equation 4) households: ${ }^{13}$

[3] $\quad y_{i}^{g}=x_{i}^{g} \beta^{g}+L_{1}^{g}+L_{2}^{g}+\varepsilon_{i}^{g}$

[4] $y_{i}^{n g}=x_{i}^{n g} \beta^{n g}+L_{1}^{n g}+L_{2}^{n g}+\varepsilon_{i}^{n g}$

In each equation, $y$ is equal to the natural logarithm of a household's total medical expenditures

(both insured and uninsured), and $x$ is a vector containing information on the age and race of each

household head, the family size, whether or not the head completed high school, the household income, and whether or not anyone in the household has a chronic illness. In addition, $x$ includes information on the head's occupation, and whether someone in the household received free medical care. The selection terms $(L)$ are constructed using estimates obtained from the first-stage bivariate probit results, and control for unobservable selection into either commercial insurance plans or Blue Cross plans. The signs on the estimated coefficients on the selection terms cannot be easily interpreted (Dolton and Makepeace, 1987).

\footnotetext{
${ }^{13}$ See Schmertmann (1994) for more details. The dependent variables $y_{m}$ are measured as the natural logarithm of total medical expenditures (with $\$ 1$ added to avoid taking the log of zero). While it may be preferable to use a model that takes into account the fact that some households report zero total medical expenditures, OLS estimation is used because less than one percent of the observations are limit observations. In addition, it is important to note that given the high degree of complexity in the model, it is virtually impossible to correct the standard errors of the estimates in the second stage. Thus, the second stage estimates must be interpreted with a degree of caution. The variables firm size, union membership, and industry dummies are included in the first stage but excluded from the second so that the system is identified.
} 
As a result, the effect of selection can best be viewed by analyzing the regression results before and after selection terms are added. Table 5 presents results with and without selection controls.

Columns (1) and (2) in Table 5 show results for the group market. In column (1), the estimated coefficient on the dummy controlling for Blue Cross/Blue Shield coverage shows that families with Blue Cross and Blue Shield spent 39 percent more on medical care than did uninsured families, while families enrolled in commercial plans spent 36 percent more. Family size, income, education, and the presence of a chronic illness in a family are all positive, statistically significant predictors of household medical expenditures, and families who were recipients of some kind of free medical care spent more on medical expenditures than families who did not receive the free care.

As shown in column (2), adding controls for unobserved selection causes the estimated coefficients on the Blue Cross and commercial health insurance dummies to rise, even though the estimated coefficients on the selection controls are themselves insignificant and the coefficients on the other variables change only slightly. ${ }^{14}$ The estimated coefficient on the Blue Cross/Blue Shield plan dummy rises from 0.39 to 0.52 , while the estimated coefficient on the commercial plan dummy rises the same amount, from 0.36 to 0.49 . This rise in the estimated coefficients indicates that failure to control for unobserved selection decreases the estimated coefficients. That is, in the group market the effect of selection is to decrease medical expenditures - selection is favorable. The households buying insurance tend to spend less on medical care than did other households, a result that may not be surprising given that most group insurance was marketed to relatively young, working families. The fact that the estimated coefficients rise when selection is controlled for indicates that at least in the group market, both commercial and Blue Cross/Blue Shield health insurance plans did not suffer from adverse selection. Quite to the contrary, the plans may have benefited from favorable selection, as workers enrolling in these group health insurance plans were healthier than average.

\footnotetext{
${ }^{14}$ Again, these estimates must be viewed cautiously given that the standard errors in the second stage have not been corrected.
} 
In the individual market, the results are very different, as shown in columns (3) and (4). There is a large difference between the estimated coefficients on the Blue Cross/Blue Shield and commercial health insurance plan dummies, and the estimated coefficients on these variables fall when controls for unobservable selection are added. The effect of selection is to increase medical expenditures - so that selection is adverse in the individual health insurance market. The nine percentage point decline in the estimated coefficient on the Blue Cross/Blue Shield dummy from 0.57 to 0.48 and the six percentage point decrease in the estimated coefficient on the commercial health insurance dummy indicate that adverse selection may have hampered companies in the individual market, and that Blue Cross/Blue Shield plans may have felt these effects to a greater extent than did the commercial plans. While the selection terms are not statistically significant, these results do provide at least some confirmation for the hypothesis that the Blues suffered from more adverse selection relative to the commercial plans, possibly because they did not rigorously screen their applicants.

\section{DISCUSSION}

In the 1930s, Blue Cross and Blue Shield developed to offer pre-paid health insurance on a community-rated basis. Early on, the Blues faced little competition from commercial, for-profit insurance companies. However, when commercial insurance companies did begin to enter the health insurance market, they experience-rated their policies, offering the lowest-risk subscribers lower premiums than the Blues could offer. Did the Blues suddenly face an adverse selection death spiral?

This paper uses a unique data set from 1957 to answer this question. In 1957, the Blues engaged in limited experience rating in the group market, but continued to community rate their individual business. Further, unlike commercial health insurance firms, the Blues did not rigorously screen potential subscribers in the individual market. As a result, persons who could not qualify for commercial health insurance because of a medical condition that could only be detected by taking a detailed medical history or by undergoing a physical examination may have been able to purchase health insurance from the 
Blues. If so, then these enrollees would drive up the Blues' costs, leading to increased premiums, and potentially causing an adverse selection death spiral.

This paper analyzes the difference in medical expenditures between Blue Cross/Blue Shield households and those households insured with commercial firms in order determine whether or not the Blues suffered from adverse selection in the 1950s. Medical expenditures for Blue Cross/Blue Shield subscribers in the individual health insurance market were higher than they were for commercial health insurance policyholders, even after controlling for differences in age, income, education and other variables. A selection model offers further, albeit limited, support for the hypothesis that the Blues suffered more from adverse selection than did commercial firms in the individual health insurance market.

However, in the group market, there is little evidence to suggest that the Blues suffered more from adverse selection than commercial firms. Medical expenditures for enrollees in both types of health insurance plans are similar, even after controlling for differences in age, income, and other variables. Controlling for selection does little to change the outcome. If anything, Blue Cross/Blue Shield plans and commercial health insurance companies both seemed to equally benefit from favorable selection in the group market. Part of the reason for this is undoubtedly because the Blues countered the adverse selection death spiral caused by the entry of commercial firms by engaging in experience rating in the group market, at least for their largest accounts.

A shortcoming of the paper is that results are based on only one year of data. The paper finds evidence that in that year, the Blues suffered from adverse selection in the individual market, although they did not suffer from adverse selection in the group market. While it is beyond the scope of this paper to determine why Blue Cross and Blue Shield continued to move towards experience-rating, findings in the paper certainly suggest that as the Blues faced continued competition from commercial firms, problems with adverse selection may have eroded their ability to community rate their policies. In 1957 , they suffered from adverse selection in the individual market, since they relied solely on community rating and did not screen potential enrollees. In the group market, their ability to avoid adverse selection 
even when engaging in very limited experience rating suggests that moving to experience rating helped them to overcome problems related to selection. Ultimately, Blue Cross and Blue Shield may have faced two choices: succumb to the adverse selection death spiral, or experience rate their policies to more effectively compete with commercial firms. 


\section{REFERENCES}

Anderson, Odin W., Collette, Patricia and Jacob J. Feldman. Changes in Family Medical Care Expenditures and Voluntary Health Insurance; a Five-Year Resurvey. Cambridge: Harvard University Press, 1963.

Buchmueller, Thomas and John DiNardo. "Did Community Rating Induce an Adverse Selection Death Spiral? Evidence from New York, Pennsylvania, and Connecticut." American Economic Review, March 2002, 92(1), pp. 280-94.

Cunningham III, Robert and Robert M. Cunningham, Jr. The Blues: A History of the Blue Cross and Blue Shield System. Dekalb: Northern Illinois University Press, 1997.

Cutler, David M. and Sarah J. Reber. "Paying for Health Insurance: The Trade-Off Between Competition and Adverse Selection." Quarterly Journal of Economics, May 1998, 113(2), 433-466.

and Richard J. Zeckhauser. "Adverse Selection in Health Insurance," in Frontiers in Health Policy Research, Vol. 1, ed. Alan M. Garber. Cambridge, MA and London: National Bureau of Economic Research and The MIT Press, 1998.

Dolton, P.J. and G.H. Makepeace. "Interpreting Sample Selection Effects.” Economic Letters, 24 (1987) pp. 373-379.

Dubin, Jeffrey A. and Daniel L. McFadden. "An Econometric Analysis of Residential Electric Appliance Holdings and Consumption.” Econometrica, March 1984, 52(2), 345-62.

Eilers, Robert D. Regulation of Blue Cross and Blue Shield Plans. Homewood, Illinois: Richard D. Irwin, Inc., 1963.

Hay, J.W. Occupational Choice and Occupational Earnings: Selectivity Bias in a Simultaneous LogitOLS Model. Unpublished Ph.D. dissertation, Yale University, 1980.

Heckman, James J. "The Common Structure of Statistical Models of Truncation, Sample Selection and Limited Dependent Variables and a Simple Estimator for Such Models." Annals of Economic and Social Measurement, 1976, 5, 475-92.

---------. “Sample Selection Bias as a Specification Error.” Econometrica, 1979, 47, 153-61.

House of Representatives, $83^{\text {rd }}$ Congress, $2^{\text {nd }}$ Session, Hearings before the Committee on Interstate and Foreign Commerce. "Health Inquiry (Voluntary Health Insurance), Parts 1-8" Washington, D.C.: U.S. Government Printing Office, 1954.

Maddala, G.S. Limited-Dependent and Qualitative Variables in Econometrics. Cambridge: Cambridge University Press, 1983.

Reed, Louis. Blue Cross and Medical Service Plans. Washington, D.C.: U.S. Public Health Service, 1947.

Rothschild, Michael and Joseph E. Stiglitz. "Equilibrium in Competitive Insurance Markets: An Essay on the Economics of Imperfect Information.” Quarterly Journal of Economics, November 1976, 90(4), 630-49. 
Schmertmann, Carl P. "Selectivity Bias Correction Methods in Polychotomous Sample Selection Models." Journal of Econometrics, 1994, 60, 101-32.

Sherrid, Pamela . "A big case of the Blues." U.S. News and World Report, November 4, 1996, pp. 51-52.

Source Book of Health Insurance Data 1976-1977. New York: Health Insurance Institute, 1977.

United States General Accounting Office. "Health Insurance: Comparing Blue Cross and Blue Shield Plans with Commercial Insurers." U.S. GAO Report \# HRD-86-110. Washington, D.C.: USGPO, 1986. 
J्ठ

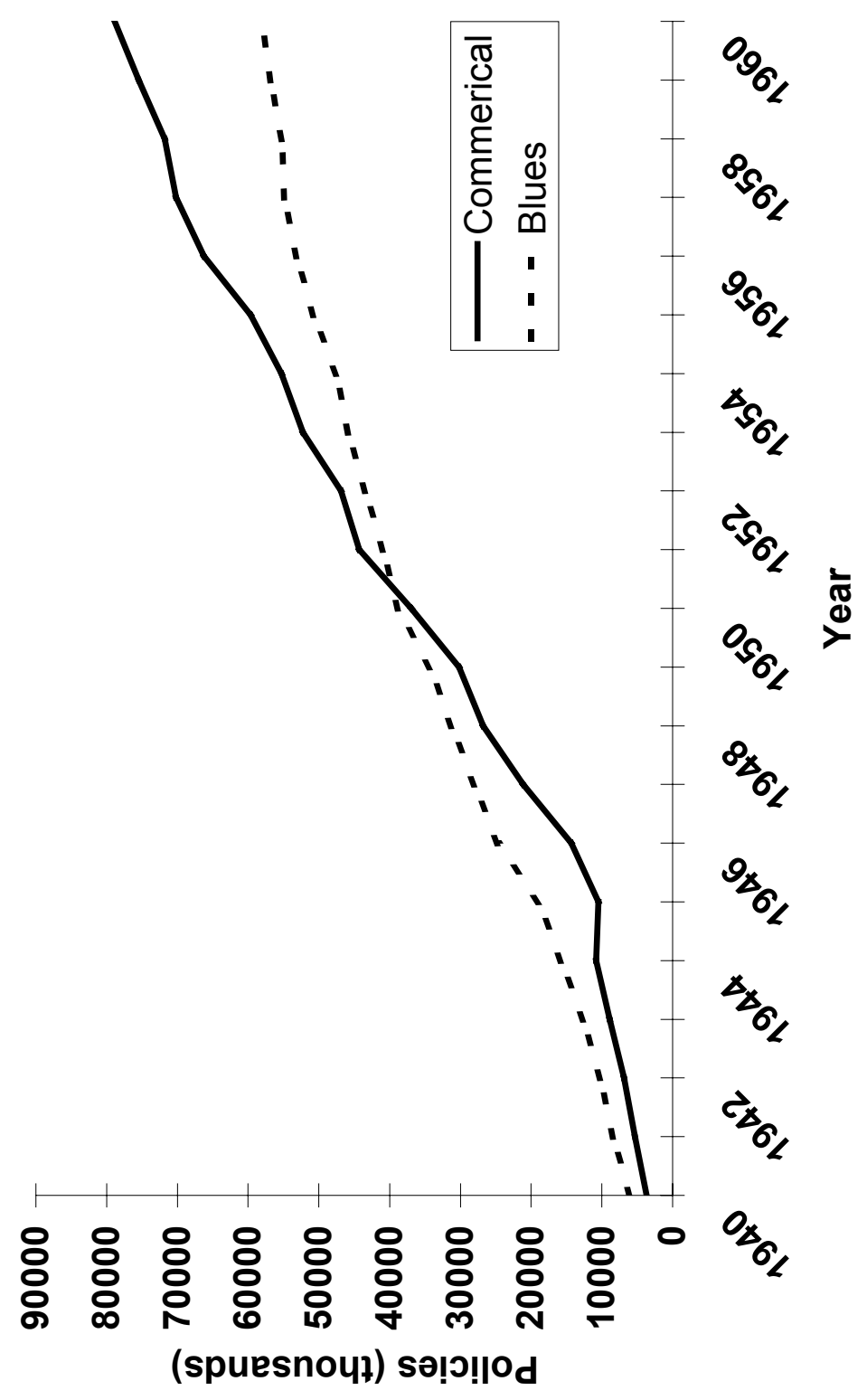


Table 1: Rating Methods Used by Blue Cross Plans, 1959

\begin{tabular}{ll}
\hline Type of Rating & Percentage of Plans \\
\hline \hline
\end{tabular}

Community Rating Only

$28.2 \%$

Community Rating with Experience Rating only for National Accounts

$16.7 \%$

Community Rating with Experience Rating Optional for Large Groups

Community Rating with Experience Rating Required for all Large Groups

$21.8 \%$

Notes: Information on 78 Blue Cross plans nationwide. National accounts were typically accounts with large firms engaged in interstate operations.

Source: Eilers, p. 218. 


\section{Table 2: $\quad 1958$ NORC Survey, Selected Summary Statistics}

\begin{tabular}{|c|c|}
\hline Variable & $\begin{array}{c}\text { Mean } \\
\text { (Std. Dev) }\end{array}$ \\
\hline Insured & $\begin{array}{c}0.727 \\
(0.446) \\
0.362\end{array}$ \\
\hline Blue Cross/Blue Shield Insurance & $(0.481)$ \\
\hline Group & $\begin{array}{c}0.254 \\
(0.436) \\
0.107\end{array}$ \\
\hline Individual & $\begin{array}{c}(0.309) \\
0.366\end{array}$ \\
\hline Commercial Insurance & $\begin{array}{c}(0.482) \\
0.263\end{array}$ \\
\hline Group & $\begin{array}{c}(0.441) \\
0.102\end{array}$ \\
\hline Individual & $\begin{array}{c}(0.303) \\
429\end{array}$ \\
\hline Total Medical Expenses & $\begin{array}{l}(570) \\
0.197\end{array}$ \\
\hline Chronic Illness & $\begin{array}{c}(0.398) \\
0.050\end{array}$ \\
\hline Received Free Medical Care & $\begin{array}{c}(0.218) \\
47.4\end{array}$ \\
\hline Age & $\begin{array}{c}(15.4) \\
3.26\end{array}$ \\
\hline Family Size & $\begin{array}{l}(1.77) \\
0.081\end{array}$ \\
\hline Black & $\begin{array}{c}(0.274) \\
0.153\end{array}$ \\
\hline Female Head & $\begin{array}{c}(0.360) \\
0.291\end{array}$ \\
\hline High School Graduate & $\begin{array}{c}(0.454) \\
5,484\end{array}$ \\
\hline Income & $\begin{array}{c}(4,208) \\
0.791\end{array}$ \\
\hline Employed & $\begin{array}{c}(0.407) \\
4.836\end{array}$ \\
\hline Union Member & $\begin{array}{c}(2.934) \\
0.304 \\
(0.460)\end{array}$ \\
\hline
\end{tabular}

Notes: Standard deviation in parentheses. $\mathrm{N}=2$,260. Firm size $=1$ denotes $1-2$ employees; firm size $=2$ denotes 3-4 employees; firm size $=3$ denotes 5-9 employees; firm size $=4$ denotes $10-20$ employees; firm size $=5$ denotes $21-50$ employees; firm size $=6$ denotes $51-100$ employees; firm size $=7$ denotes $101-500$ employees; firm size $=8$ denotes over 500 employees.

Source: Nationwide Family Expenditures Surveys, 1958. 


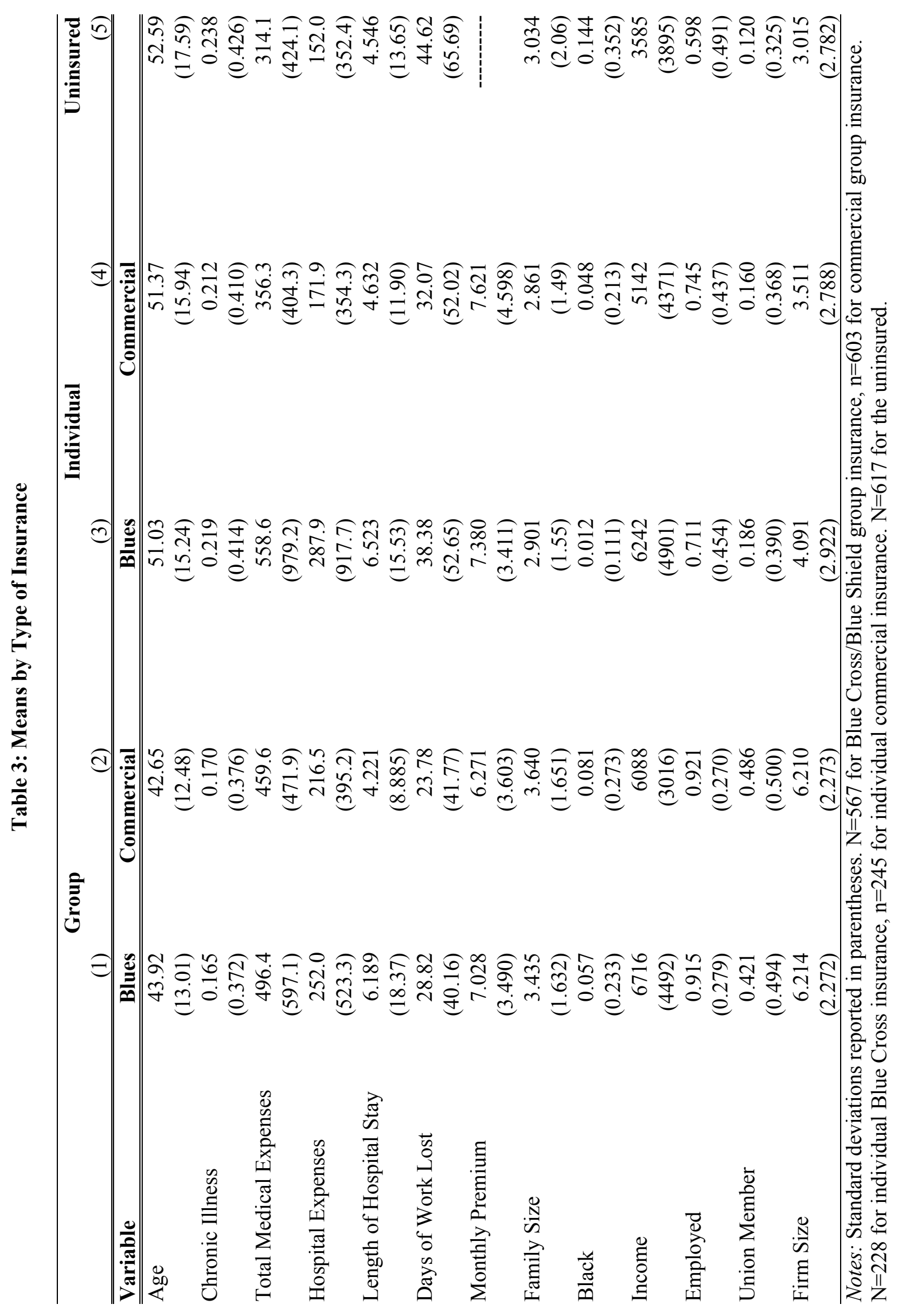


Table 4: $\quad$ OLS Estimation of Ln(Total Medical Expenditures), 1958

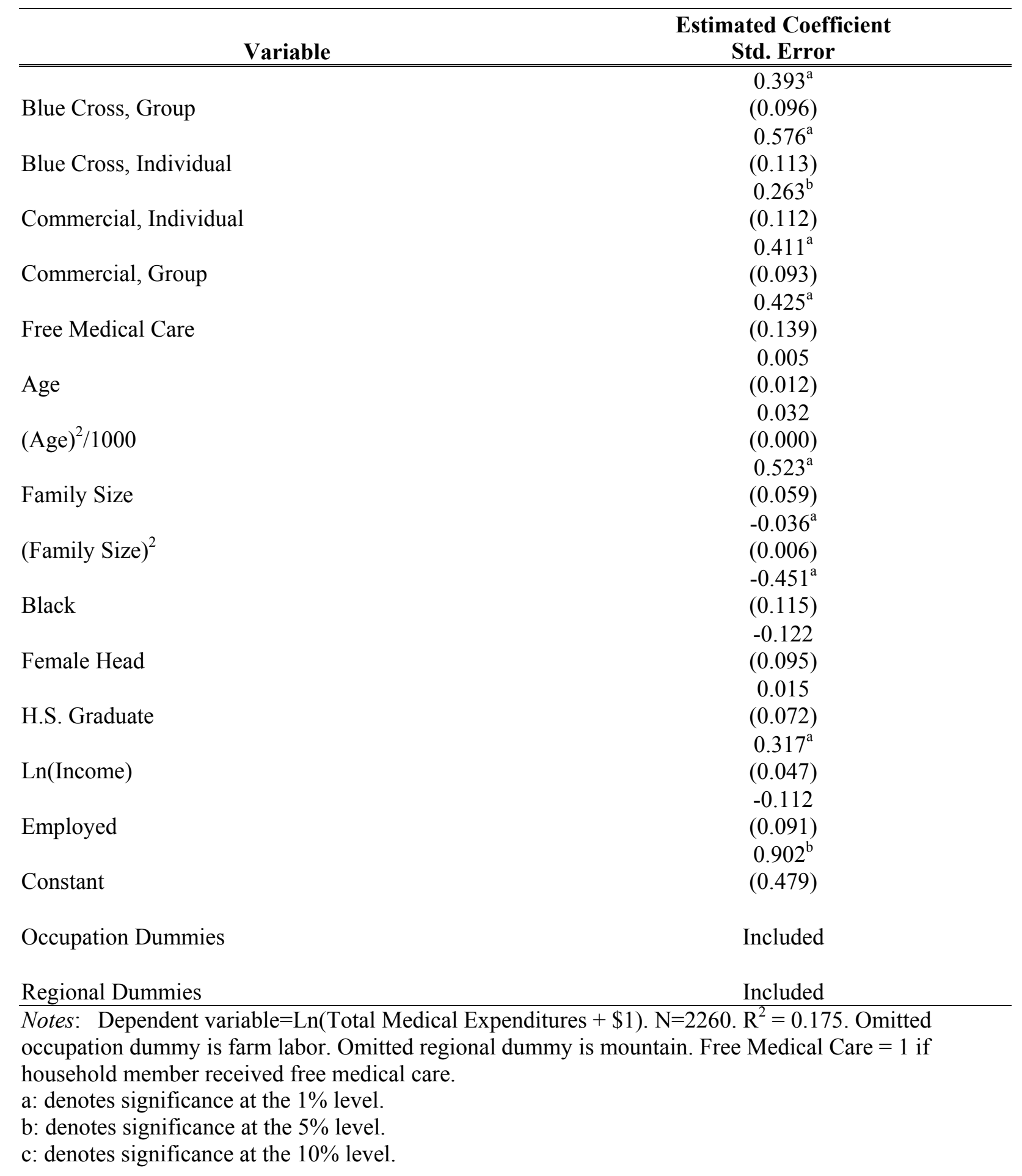


Table 5: $\quad$ Estimation with and without Controls for Selection

\begin{tabular}{|c|c|c|c|c|}
\hline \multirow{3}{*}{ Variable } & \multicolumn{2}{|c|}{ Group Market, n=1249 } & \multicolumn{2}{|c|}{ Individual Market, $\mathrm{n}=1011$} \\
\hline & $(1)$ & $(2)$ & (3) & (4) \\
\hline & Est. Coefficient & Est. Coefficient & Est. Coefficient & Est. Coefficient \\
\hline $\begin{array}{l}\text { Blue Cross/Blue Shield } \\
\text { Insurance }\end{array}$ & $\begin{array}{l}0.386^{\mathrm{b}} \\
(0.158)\end{array}$ & $\begin{array}{l}0.521^{\mathrm{a}} \\
(0.197)\end{array}$ & $\begin{array}{l}0.568^{\mathrm{a}} \\
(0.127)\end{array}$ & $\begin{array}{l}0.484^{\mathrm{a}} \\
(0.171)\end{array}$ \\
\hline Commercial Insurance & $\begin{array}{l}0.362^{b} \\
(0.158)\end{array}$ & $\begin{array}{l}0.493^{\mathrm{a}} \\
(0.194)\end{array}$ & $\begin{array}{l}0.273^{\mathrm{b}} \\
(0.123)\end{array}$ & $\begin{array}{c}0.210 \\
(0.179)\end{array}$ \\
\hline Selection 1 & Not included & $\begin{array}{c}-0.312 \\
(0.273)\end{array}$ & Not included & $\begin{array}{c}0.294 \\
(0.274)\end{array}$ \\
\hline Selection 2 & Not included & $\begin{array}{c}0.128 \\
(0.167)\end{array}$ & Not included & $\begin{array}{l}-0.357 \\
(0.298)\end{array}$ \\
\hline Age & $\begin{array}{c}0.003 \\
(0.018)\end{array}$ & $\begin{array}{c}0.003 \\
(0.018)\end{array}$ & $\begin{array}{l}-0.012 \\
(0.018)\end{array}$ & $\begin{array}{l}-0.014 \\
(0.018)\end{array}$ \\
\hline Family Size & $\begin{array}{c}0.619^{\mathrm{a}} \\
(0.081)\end{array}$ & $\begin{array}{c}0.620^{\mathrm{a}} \\
(0.081)\end{array}$ & $\begin{array}{c}0.386^{\mathrm{a}} \\
(0.085)\end{array}$ & $\begin{array}{c}0.393^{\mathrm{a}} \\
(0.086)\end{array}$ \\
\hline Ln(Income) & $\begin{array}{l}0.263^{\mathrm{a}} \\
(0.064)\end{array}$ & $\begin{array}{l}0.268^{\mathrm{a}} \\
(0.065)\end{array}$ & $\begin{array}{l}0.381^{\mathrm{a}} \\
(0.063)\end{array}$ & $\begin{array}{l}0.381^{\mathrm{a}} \\
(0.063)\end{array}$ \\
\hline Black & $\begin{array}{l}-0.221 \\
(0.150)\end{array}$ & $\begin{array}{c}-0.212 \\
(0.151)\end{array}$ & $\begin{array}{l}-0.690^{\mathrm{a}} \\
(0.170)\end{array}$ & $\begin{array}{l}-0.679^{\mathrm{a}} \\
(0.173)\end{array}$ \\
\hline Female Head & $\begin{array}{l}-0.416^{\mathrm{a}} \\
(0.141)\end{array}$ & $\begin{array}{l}-0.410^{\mathrm{a}} \\
(0.142)\end{array}$ & $\begin{array}{c}0.090 \\
(0.126)\end{array}$ & $\begin{array}{c}0.104 \\
(0.126)\end{array}$ \\
\hline H.S. Graduate & $\begin{array}{l}0.150^{\mathrm{c}} \\
(0.089)\end{array}$ & $\begin{array}{l}0.153^{\mathrm{c}} \\
(0.089)\end{array}$ & $\begin{array}{l}-0.140 \\
(0.113)\end{array}$ & $\begin{array}{l}-0.123 \\
(0.114)\end{array}$ \\
\hline Free Medical Care & $\begin{array}{l}0.439^{b} \\
(0.193)\end{array}$ & $\begin{array}{l}0.419^{b} \\
(0.194)\end{array}$ & $\begin{array}{c}0.262 \\
(0.197)\end{array}$ & $\begin{array}{c}0.272 \\
(0.197)\end{array}$ \\
\hline Chronic Illness & $\begin{array}{l}0.756^{\mathrm{a}} \\
(0.098)\end{array}$ & $\begin{array}{l}0.757^{\mathrm{a}} \\
(0.098)\end{array}$ & $\begin{array}{l}0.972^{\mathrm{a}} \\
(0.113)\end{array}$ & $\begin{array}{c}0.980^{\mathrm{a}} \\
(0.114)\end{array}$ \\
\hline Occupation Dummies & Included & Included & Included & Included \\
\hline Regional Dummies & Included & Included & Included & Included \\
\hline
\end{tabular}

Notes: The dependent variable is Ln(Medical Expenditures $+\$ 1)$. All regressions include controls for occupation and region. Selection variables are constructed using estimates from first-stage bivariate probit (results in appendix). Variables omitted here but included in the first-stage include firm size, lodge, industry dummies, and union membership. $\mathrm{R}^{2}=.184$ for column (1), $\mathrm{R}^{2}=.185$ for column (2), $\mathrm{R}^{2}=.237$ for column (3), and $\mathrm{R}^{2}=.239$ for column (4).

a: denotes significance at the $1 \%$ level.

b: denotes significance at the $5 \%$ level.

c: denotes significance at the $10 \%$ level. 


\section{Appendix 1: Bivariate Probit Results}

\begin{tabular}{|c|c|c|c|c|}
\hline \multirow[b]{2}{*}{ Variable } & \multicolumn{2}{|c|}{ Individual Market, $\mathrm{n}=1011$} & \multicolumn{2}{|c|}{ Group Market, $n=1249$} \\
\hline & Equation 1 & Equation 2 & Equation 1 & Equation 2 \\
\hline Constant & $\begin{array}{c}0.042 \\
(0.530)\end{array}$ & $\begin{array}{c}-0.097 \\
(0.539)\end{array}$ & $\begin{array}{c}0.154 \\
(0.972)\end{array}$ & $\begin{array}{c}0.042 \\
(1.024)\end{array}$ \\
\hline Family Size & $\begin{array}{l}-0.168^{c} \\
(0.125)\end{array}$ & $\begin{array}{l}-0.205^{b} \\
(0.115)\end{array}$ & $\begin{array}{l}-0.109 \\
(0.147)\end{array}$ & $\begin{array}{c}0.017 \\
(0.157)\end{array}$ \\
\hline Age & $\begin{array}{l}-0.540^{\mathrm{a}} \\
(0.209)\end{array}$ & $\begin{array}{c}-0.215 \\
(0.237)\end{array}$ & $\begin{array}{l}-0.432^{b} \\
(0.258)\end{array}$ & $\begin{array}{c}-0.191 \\
(0.342)\end{array}$ \\
\hline $\operatorname{Ln}($ Income $)$ & $\begin{array}{c}0.182^{\mathrm{a}} \\
(0.048)\end{array}$ & $\begin{array}{c}0.102^{\mathrm{c}} \\
(0.074)\end{array}$ & $\begin{array}{c}0.370^{\mathrm{b}} \\
(0.178)\end{array}$ & $\begin{array}{c}0.164 \\
(0.288)\end{array}$ \\
\hline Union Member & $\begin{array}{c}0.022 \\
(0.024)\end{array}$ & $\begin{array}{c}0.016 \\
(0.023)\end{array}$ & $\begin{array}{c}0.100 \\
(0.102)\end{array}$ & $\begin{array}{c}0.132^{b} \\
(0.089)\end{array}$ \\
\hline Lodge Member & $\begin{array}{c}0.058^{\mathrm{b}} \\
(0.032)\end{array}$ & $\begin{array}{c}0.045^{\mathrm{c}} \\
(0.035)\end{array}$ & $\begin{array}{c}0.029 \\
(0.043)\end{array}$ & $\begin{array}{c}0.018 \\
(0.044)\end{array}$ \\
\hline Black & $\begin{array}{l}-0.116^{\mathrm{a}} \\
(0.029)\end{array}$ & $\begin{array}{l}-0.066^{\mathrm{a}} \\
(0.025)\end{array}$ & $\begin{array}{c}0.002 \\
(0.022)\end{array}$ & $\begin{array}{c}0.004 \\
(0.021)\end{array}$ \\
\hline Female Head & $\begin{array}{c}0.041 \\
(0.035)\end{array}$ & $\begin{array}{c}-0.018 \\
(0.035)\end{array}$ & $\begin{array}{c}0.009 \\
(0.026)\end{array}$ & $\begin{array}{c}0.010 \\
(0.027)\end{array}$ \\
\hline H.S. Graduate & $\begin{array}{c}0.088^{\mathrm{a}} \\
(0.038)\end{array}$ & $\begin{array}{c}-0.019 \\
(0.042)\end{array}$ & $\begin{array}{c}-0.067 \\
(0.075)\end{array}$ & $\begin{array}{c}0.075 \\
(0.071)\end{array}$ \\
\hline Firm Size & $\begin{array}{c}0.256^{\mathrm{a}} \\
(0.081)\end{array}$ & $\begin{array}{c}0.049 \\
(0.099)\end{array}$ & $\begin{array}{c}0.382^{c} \\
(0.266)\end{array}$ & $\begin{array}{c}0.351 \\
(0.282)\end{array}$ \\
\hline Free Care & $\begin{array}{c}-0.006 \\
(0.015)\end{array}$ & $\begin{array}{c}-0.015 \\
(0.015)\end{array}$ & $\begin{array}{l}-0.017^{\mathrm{c}} \\
(0.011)\end{array}$ & $\begin{array}{c}-0.013 \\
(0.013)\end{array}$ \\
\hline Chronic Illness & $\begin{array}{l}-0.024 \\
(0.030)\end{array}$ & $\begin{array}{c}-0.024 \\
(0.028)\end{array}$ & $\begin{array}{c}0.011 \\
(0.030)\end{array}$ & $\begin{array}{c}0.008 \\
(0.030)\end{array}$ \\
\hline Veteran & $\begin{array}{c}0.019 \\
(0.036)\end{array}$ & $\begin{array}{c}0.004 \\
(0.034)\end{array}$ & $\begin{array}{c}0.032 \\
(0.071)\end{array}$ & $\begin{array}{c}0.036 \\
(0.070)\end{array}$ \\
\hline Employed & $\begin{array}{c}0.067 \\
(0.106)\end{array}$ & $\begin{array}{c}0.224^{\mathrm{a}} \\
(0.088)\end{array}$ & $\begin{array}{c}0.158 \\
(0.317)\end{array}$ & $\begin{array}{c}0.442^{a} \\
(0.196)\end{array}$ \\
\hline $\begin{array}{l}\text { Occupation } \\
\text { Dummies }\end{array}$ & Included & Included & Included & Included \\
\hline $\begin{array}{l}\text { Industry } \\
\text { Dummies }\end{array}$ & Included & Included & Included & Included \\
\hline $\begin{array}{l}\text { Regional } \\
\text { Dummies }\end{array}$ & Included & Included & Included & Included \\
\hline Rho & $\begin{array}{l}0.131 \\
0.911 \\
\end{array}$ & & $\begin{array}{l}0.004 \\
1.582 \\
\end{array}$ & \\
\hline
\end{tabular}

Notes: Results from bivariate probit estimation of equations [1] for the individual market $(\mathrm{n}=1011)$ and group market $(\mathrm{n}=1249)$. Variables included in Stage 1 but omitted from stage 2 (Table 6) include firm size, industry dummies, union membership and lodge membership.

a: denotes significance at the $1 \%$ level.

b: denotes significance at the $5 \%$ level.

c: denotes significance at the $10 \%$ level. 